\title{
The Effects of Manipulating Task Complexity on the Occurrence of Language-related Episodes during Learner-learner Interaction
}

\author{
Mohammad Ali Heidari-Shahreza, Azizollah Dabaghi and \\ ZOHREH KaSSAIAN \\ Department of English, Faculty of Foreign Languages, University of Isfahan, Iran
}

Received: 25 March 2011 / Accepted: 8 September 2011

ISSN: $1697-7467$

\begin{abstract}
The present study explored the effects of task complexity on the occurrence of language-related episodes during learner-learner interaction of $40 \mathrm{EFL}$ students. Task complexity was manipulated using two factors: (1) reasoning demands; and (2) number of elements. Participants performed four tasks of two types (picture narration and picture difference). The study bore mixed results; while in some versions of the tasks, complexity and the occurrence of LREs positively correlated, this pattern did not hold true for all the tasks and proficiency levels. Moreover, the observed increase was mostly in the number of lexical LREs than that of grammatical ones. Keywords: Task complexity, learner-learner interaction, EFL learners, Languagerelated episodes
\end{abstract}

Efectos de la manipulación de la complejidad de la tarea en el uso de episodios lingüísticos durante la interacción entre el alumnado

RESUMEN: El presente estudio exploró los efectos de la complejidad de la tarea en el uso de episodios relacionados con el lenguaje en la interacción alumno-alumno de 40 estudiantes de inglés como lengua extranjera. La complejidad de la tarea fue manipulada mediante dos factores: (1) exigencia de razonamiento, y (2) el número de elementos. Los participantes realizaron cuatro tareas de dos tipos (la narración de imagen y la diferencia de imagen). El estudio dio resultados mixtos, mientras que en algunas versiones de las tareas, la complejidad y la aparición de LRE mostró una correlación positiva, este patrón no es válido para todas las tareas y niveles de competencia. Por otra parte, el aumento observado fue en su mayoría en el número de LRE léxica y no en los elementos gramaticales.

Palabras clave: La complejidad de tareas, la interacción alumno-alumno, los estudiantes de inglés como lengua extranjera, los episodios relacionados con la lengua

\section{INTRODUCTION}

Since the introduction of task-based language pedagogy in the 1980s, tasks have held a central place in second language acquisition (SLA) research and in language pedagogy as primary instructional tools or building blocks of classroom language learning. 
For this reason, over the past decades a growing number of studies have paid attention to the use of tasks and the benefits of learner-learner interaction during collaborative meaning-oriented task-based language learning (e.g., Bygate et al., 2001; Crookes and Gass, 1993a, 1993b; Ellis, 2003; Samuda and Bygate, 2008, Kim, 2009).

Within the framework of the Interaction Hypothesis, some researchers have suggested that the performance of interactive tasks can bring about interactional processes such as negotiation of meaning, provision of feedback, and production of modified output which can be helpful in L2 development (e.g., Gass and Mackey, 2007; Mackey, 2007a, 2007b; McDonough, 2004). In this regard, language-related episodes (LREs) have been of primary importance. Because LREs are learning opportunities in which learners focus on form, negotiate meaning and provide feedback to deal with the challenge imposed by a task (Gass and Mackey, 2007; Leeser, 2004; Swain and Lapkin, 1998; Williams, 2001). Within the perspective of LREs, a central issue to investigate concerns the influence of task complexity on learners' interaction (for an overview, see Robinson, 2001a, and 2005).

\subsection{Task complexity, Robinson's Hypothesis and Skehan's Model}

In order to situate our study, we first review the two recent competing theoretical frameworks on task complexity in task-based SLA research: Robinson's Cognition Hypothesis (2001a, 2001b, 2003, 2005, and 2007) and Skehan's Limited Attentional Capacity Model (Skehan \& Foster, 1999, 2001). According to Robinson (2001a, 2001b, 2005, 2007), task complexity refers to the cognitive task features which can be manipulated either to increase or decrease cognitive demands placed on the learners when they perform a task (Ong and Zhang, 2010). Based on his Cognition Hypothesis task complexity encompasses two key dimensions, resource-directing and resource-dispersing (see Table 1).The resourcedirecting dimensions make conceptual demands whilst the resource-dispersing dimensions make procedural demands on learners. Robinson (2001a, 2001b, 2003, and 2005) argues that increasing task complexity with respect to resource-directing factors enhances complexity and accuracy but reduces fluency.

Table 1. Robinson's Task Complexity Dimensions.

\begin{tabular}{ll}
\hline Resource-directing Dimension & Resource-dispersing Dimension \\
\hline \pm few elements & \pm planning \\
\pm here-and-know & \pm single task \\
\pm reasoning demands & \pm prior knowledge \\
\hline
\end{tabular}

In contrast, Skehan's Limited Attentional Capacity Model (Skehan, 1998; Skehan \& Foster, 2001, 2005) assumes that humans have a limited information processing capacity. 
Therefore, increasing task complexity would result in trade-off effects among the three aspects of language production: accuracy, fluency, and complexity (Skehan \& Foster, 1999, 2001, 2005). Similarly, VanPatten (1990) points out that due to learners' limited working memory, they may have difficulty in attending to both form and meaning concurrently and, accordingly, learners will prioritize content over form. These researchers argue that content will be traded off for accuracy and complexity, and vice versa (Foster \& Skehan, 1996; Skehan \& Foster, 1997; VanPatten, 1990).

\section{Literature ReVIEW}

Previous studies on the effects of task complexity have largely addressed such issues as L2 written production (Kuiken \& Vedder, 2008; Ojima, 2006), fluency and lexical complexity (Ong \& Zhang, 2010), etc. Therefore, there are few studies in the literature which have investigated the effects of task complexity on learner-leaner interaction in general and the occurrence of language-related episodes in particular. Robinson (2001a) investigated the effect of task complexity on interaction with regards to [ \pm prior knowledge] and $[ \pm$ few elements] variables in map tasks. Results showed that increasing task complexity positively correlated with the amount of interaction that occurred among learners.

In another study, Nuevo (2006) explored how manipulating task complexity with regard to [ \pm reasoning demands] variable affected L2 learning opportunities and development. Three groups of learners participated in two different tasks, picture narration tasks and decision making tasks with different levels of complexity. The learning opportunities were identified as recasts, confirmation checks, and metalinguistic talk, etc. In contrast to the prediction of Cognition Hypothesis no association was found between task complexity and L2 development. As for the occurrence of learning opportunities the study also bore mixed results.

In a recent study, Kim (2009) explored the effects of task complexity on the occurrence of LREs with a group of high and low proficiency learners. The researcher manipulated [ \pm reasoning demands] and $[ \pm$ few elements] variables in two task types: picture narration and picture difference tasks. The results indicated that the effects of task complexity on the occurrence of LREs differed depending on task types and learner proficiency. This study only partially confirmed Robinson's Hypothesis.

Although the contrasting or mixed findings of studies investigating task complexity in relation to Cognition Hypothesis somewhat favor its competing model (i.e. Skehan's Limited Attentional Resources model). It seems more research is needed to investigate task complexity and interaction within the perspective of these two models and this is indeed the incentive behind this study.

\section{Present Study}

The present study investigated the effects of increasing task cognitive complexity on the occurrence of LREs during learner-learner interaction of Iranian EFL learners. As mentioned above, two key reasons motivated the focus and orientation of this research. 
The first reason was the contrasting explanations and claims made by Skehan and Foster's (2001) Limited Attentional Capacity and Robinson's (2001a, 2001b, 2005, 2007) Cognition Hypothesis. The second reason was a scarcity of task-based research studies on learner-learner interaction in relation to the validity of these proposed models. It is hoped that this study will shed light on the contrasting theoretical explanations and claims for increasing task complexity as proposed by Skehan and Foster and Robinson, and fill in the gap in task-based SLA research with its focus on interaction.

\subsection{Research questions}

Task $1 \quad$ Task $2 \quad$ Task $3 \quad$ Task 4

Two research questions guided the study:

1. What are the effects of increased task complexity, manipulated with respect to the dimensions of (a) reasoning demands; (b) number of elements to be processed on Iranian EFL learners' occurrence of language-related episodes?

2. Do the possible effects of increased task complexity, manipulated with respect to the above dimensions vary among different proficiency levels?

\section{Methods}

\subsection{Participants}

The participants of this study were 40 EFL learners, 18 men and 22 women, who were enrolled in an English program for adult learners at a private language institute in Iran. They were grouped into two levels of proficiency (low vs. high) based on their enrollment status in the program and their paper-based placement test. Age, education and sociocultural background were kept under control.

\subsection{Materials}

\subsubsection{Tasks}

Two picture narration and two picture difference tasks were employed in the study (see table 2). Based on Robinson's task complexity criteria (see table 1 for more information), the cognitive complexity of the tasks were manipulated. As for the picture narration tasks, in the simple version, the participants were asked to narrate a comic story based on six already-ordered pictures. In the complex version, however, the pictures were not already sequenced. Hence the participants had to first put them in order and secondly narrate the story. In this way, $[ \pm$ reasoning demands] factor of the tasks were manipulated.

As for the picture difference tasks, in the simple version, the participants were asked to find the differences between a pair of pictures which showed the interior view of two apartments with a focus on the furniture and people in them. In the complex version also such pair of pictures was given to the participants, however, the number of differences 
was significantly more and needed more attention. In this way, $[ \pm$ few elements $]$ factor was manipulated. All the four tasks were piloted before the main study to ensure their interactiveness and appropriate level of complexity.

Table 2. Description of the tasks.

\begin{tabular}{lllll}
\hline & Task 1 & Task 2 & Task 3 & Task 4 \\
\hline Task type & Picture & Picture & Picture & Picture \\
& narration & narration & differences & differences \\
Complexity & - reasoning & + reasoning & + few elements & - few elements \\
factor & & & & \\
Complexity & Simple & Complex & Simple & Complex \\
level & & & & \\
\hline
\end{tabular}

\subsubsection{Questionnaire}

A questionnaire was also developed by the researcher to explore the participants' perceptions of (a) the absolute cognitive complexity of each task; (b) the relative cognitive complexity of each task in relation to its simpler or more complex version; (c) the amount of interaction entailed to perform each task (d) the learning opportunities occurred through the completion of each task (see Appendix A). In doing so, Likert-scale response items with nine scales were adapted.

\subsection{Procedure}

The experiment was conducted in six EFL classes during their regular class periods. The participants were paired randomly. Each had the same partner for every task. To control the variation in the experiment, Latin square design was employed.

\subsection{Data Analysis}

To analyze the recorded data, LREs were used as the unit of analysis. LREs indicate the interaction between learners. Through LREs, learners often request for assistance or clarification, give each other implicit and explicit feedback (Kim, 2009). They also may help learners notice the gap between their interlanguage and the target language system. In addition, some evidence suggests that correctly resolved LREs promote L2 acquisition (see Gass and Mackey, 2007 for a review) 


\subsubsection{Analysis of LRES}

Two types of LREs were in focus: (a) Grammatical LREs which refer to the interaction between learners in which some grammatical feature such as verb tense or preposition is discussed (Swain and Lapkin, 1995) and lexical LREs which refer to the discussion over (more often) meaning or spelling of words, etc. Below are instances of grammatical and lexical LREs extracted from the data obtained from picture narration task and picture difference tasks respectively:

\section{Excerpt 1: Grammatical LRE}

Participant A: I think .... She is going to the mall.

Participant B: No... she was going. This is past....

Participant A: Sorry, I forgot. She was going.....

\section{Excerpt 2: Lexical LRE}

Participant A: Look... there is easy chair in [picture] B.

Participant B: easy?!

Participant A: yeah big relaxed chair

Participant B: Yes....OK

\section{RESUlts}

The primary purpose of the present study was to investigate the relation between increased task complexity and the occurrence of LREs across low and high levels of proficiency.

As Table 3 below indicates in the picture narration task both low and high-level participants produced more LREs in the complex version of the task (60 to 70 LREs for the low group and 42 to 66 LREs for the high group). However, the results of individual Wilcoxon Signed Ranks tests indicated that only the production of high-level participants was significantly increased $(Z=-2.31, P<0.05)$. Even so, they produced much less or almost the same number of grammatical LREs in both versions of the task.

Table 3. Occurrence of LRES (picture narration task).

\begin{tabular}{ccccc}
\hline \multirow{2}{*}{ Proficiency } & Complexity & Lexical LREs & Grammatical LREs & Total \\
& & & & \\
\hline \multirow{2}{*}{ Low } & Simple & 41 & 19 & 60 \\
& Complex & 62 & 8 & 70 \\
\multirow{2}{*}{ High } & Simple & 27 & 15 & 42 \\
& Complex & 49 & 17 & 66 \\
\hline
\end{tabular}


In the picture difference task also along with the increase in task complexity (from simple to complex version), the number of LREs has increased for both groups of participants (see table 4). However, only the low-level group significantly produced more LREs in the complex version $(\mathrm{Z}=-2.28, P<0.05)$. In addition, again, the increase observed in either group is mainly related to lexical LREs; grammatical LREs follow the same pattern as observed in the picture narration task (compare table 3 and 4).

Table 4. Occurrence of LRES (picture difference task).

\begin{tabular}{ccccc}
\hline \multirow{2}{*}{ Proficiency } & Complexity & Lexical LREs & Grammatical LREs & Total \\
& & & & \\
\hline \multirow{2}{*}{ Low } & Simple & 54 & 12 & 66 \\
\multirow{2}{*}{ High } & Complex & 78 & 15 & 93 \\
& Simple & 32 & 13 & 45 \\
\hline
\end{tabular}

In addition to the occurrence of LREs, how the learners resolved the LREs in each task was analyzed in three ways: correctly resolved, unresolved, and incorrectly resolved. As figure 1 below illustrates, in both simple and complex versions of the narration task more than half of the LREs have been successfully resolved. However, there is no significant increase in the overall number of correctly resolved LREs in the complex version of the narration task.

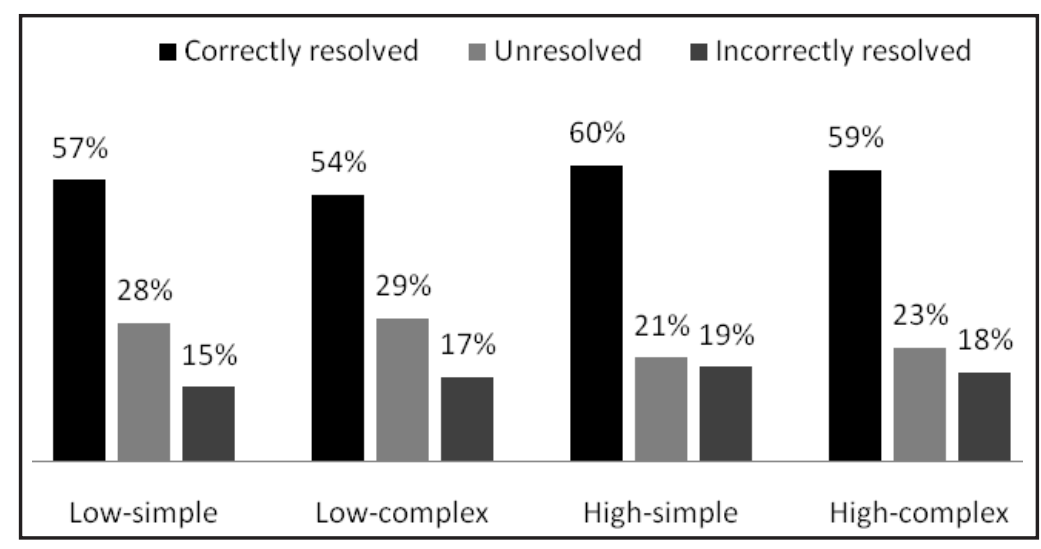

Fig. 1. Resolution of LREs (picture narration task).

Further scrutiny of the results showed that although the overall number of correctly resolved LREs has remained almost the same, for the low-group of participants the occurrence of grammatical LREs significantly decreased (see figure 2). 


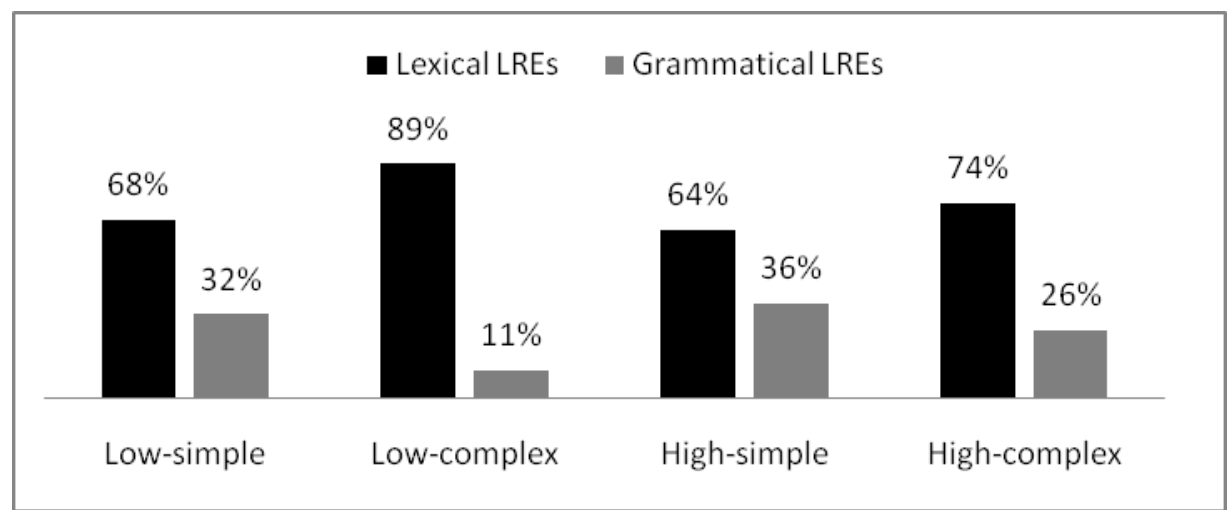

Fig. 2. Occurrence of lexical and grammatical LREs (picture narration task).

In general, no significant pattern was found for the occurrence of unresolved or incorrectly resolved LREs for both groups of participants (see table 5 for details).

Table 5. Resolution of lexical and grammatical LREs (picture narration task).

Picture narration task

\begin{tabular}{lcccc}
\hline & \multicolumn{2}{c}{ Simple } & \multicolumn{2}{c}{ Complex } \\
& Lexical & Grammatical & Lexical & Grammatical \\
Low group & & & & \\
Correctly resolved & 25 & 9 & 34 & 4 \\
\hline Unresolved & 12 & 5 & 19 & 1 \\
\hline Incorrectly resolved & 4 & 5 & 9 & 3 \\
\hline
\end{tabular}

In both versions of the picture difference task also more than half of the LREs were correctly resolved by the two groups. However, there is no significant increase in the overall number of correctly resolved LREs in the complex version of the task (see figure 3). 


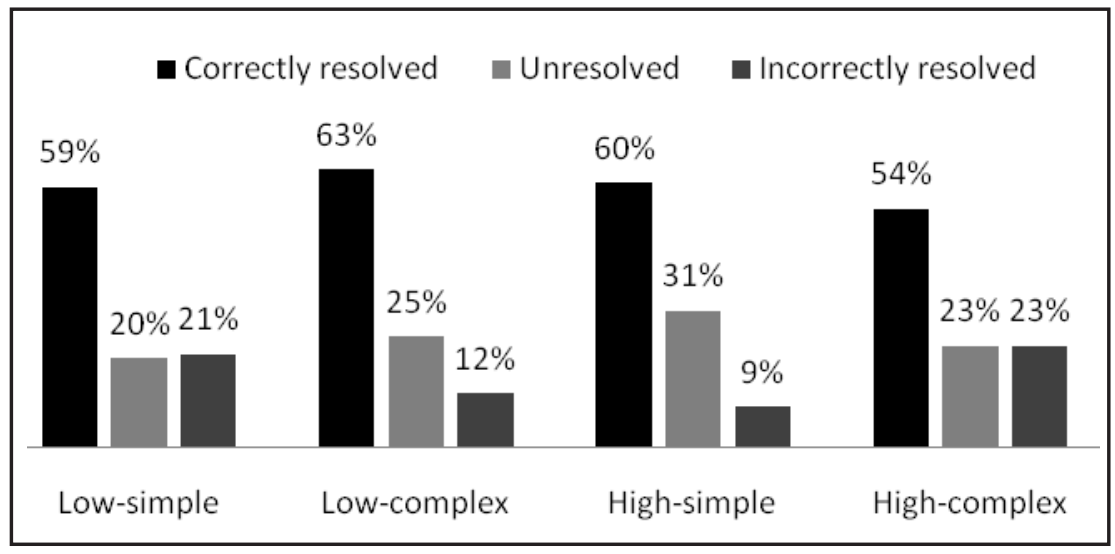

Fig. 3. Resolution of LRES (picture difference task).

In contrast to the occurrence of grammatical LREs in the narration task that decreased in the complex version of the task, here in the picture difference task, their occurrence almost remained the same (see figure 4).

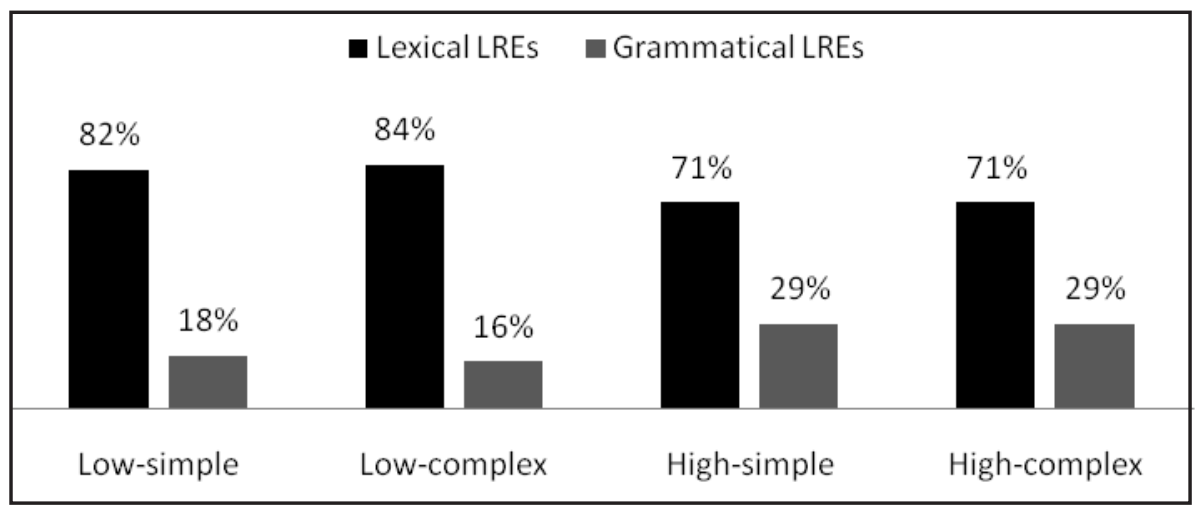

Fig. 4. Occurrence of lexical and grammatical LREs (picture difference task).

In general, no significant pattern was found for the occurrence of unresolved or incorrectly resolved LREs for both groups of participants (see table 5 for details). 
Table 6. Resolution of lexical and grammatical LREs (picture difference task).

\begin{tabular}{lcccc}
\hline & \multicolumn{4}{c}{ Picture difference task } \\
\hline & \multicolumn{2}{c}{ Simple } & \multicolumn{2}{c}{ Complex } \\
Lexical & Grammatical & lexical & Grammatical \\
Correctly resolved & 32 & 7 & 51 & 8 \\
Unresolved & 11 & 2 & 18 & 5 \\
Incorrectly resolved & 11 & 3 & 9 & 2
\end{tabular}

\begin{tabular}{lcccc} 
High group & & & & \\
\hline Correctly resolved & 20 & 7 & 23 & 4 \\
\hline Unresolved & 9 & 5 & 9 & 5 \\
\hline Incorrectly resolved & 3 & 1 & 8 & 4 \\
\hline
\end{tabular}

Moreover, despite the fact that the participants perceived the complex versions of the two task types significantly more difficult than their simple counterparts, based on the data obtained from the Likert-scale questionnaire, they did not indicate that complex tasks provided more learning opportunities than the simple ones.

\section{Task complexity $\quad$ Provision of opportunities}

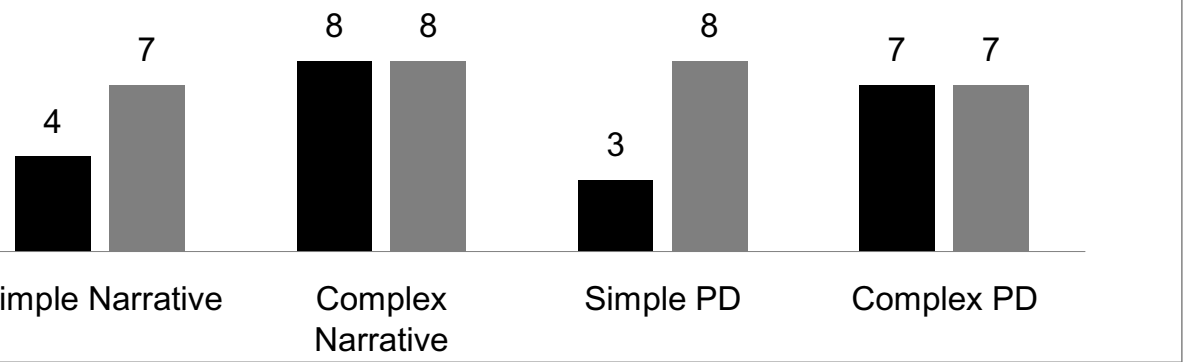

Fig. 5. Task complexity and provision of opportunities as perceived by learners.

\section{Discussion}

The present study investigated the effects of increasing task complexity on learnerlearner interaction of low and high level Iranian EFL learners. On one hand, according to Robinson's Cognition hypothesis, it was expected that as the cognitive complexity of the tasks increased, learners would notice the linguistic properties more and consequently, more interaction and learning opportunities would occur. On the other hand, based on 
Skehan's Limited Attentional Resources Model, it was expected that an increase in cognitive task complexity would divert learners' attention to the development of the content of the task, instead of focusing their attention on the complexity and accuracy of their language production and subsequently learners would prioritize content over form.

The findings of the current study bore mixed results without fully confirming either of the above-mentioned models, which is somehow in line with the previous studies (Nuevo, 2006; Kim, 2009). For instance, while against Robinson's hypothesis' predictions, low-level learners did not produce significantly more LREs in the complex version of the narration task, high-level learners did so, which supports Robinson's Hypothesis. Even so, the increased number of LREs in the complex version of the task was mainly of lexical type (i.e. grammatical LREs remained almost the same), which may indicate that learners have prioritized vocabulary to extract meaning from the input. If so, Skehan's Model is supported. In the picture difference task, the observed pattern was almost the reverse. While low-level learners produced significantly more LREs in the complex version of the task, high-level learners did not. A common point, however, was that in both task types, it was lexical LREs that increased significantly. This preference for vocabulary issues especially focus on word meaning is consistent with previous LRE studies (e.g., Kim, 2009; Kim \& McDonough, 2008; Lesser, 2004; Williams, 2009).

An important point is that regardless of the increased or decreased number of LREs in the four tasks, the overall occurrence of correctly resolved LREs is almost the same for all tasks. Therefore, if we suppose that only correctly resolved LREs have the potential to promote acquisition/learning in language learners, it might be safe to say that manipulating the cognitive demands of a task may not contribute in any significant manner to the overall acquisition/learning that takes place.

In general, learners also did not regard increasing task complexity as having a positive effective on the occurrence of more learning opportunities during task-based interaction, which is in line with the empirical findings of the study. Furthermore, although low and high level learners performed differently in some aspects, on the whole, it seems that language proficiency did not appear to play any significant role in determining the effects of task complexity in this study.

\section{Conclusion}

Based on Robinson's Cognition Hypothesis and Skehan's Model, the present study investigated how manipulating cognitive task complexity may affect the occurrence of LREs during learner-learner interaction. The findings of the study only partially confirmed the models. That is to say while in some versions of the tasks, there was positive correlation between task complexity and the occurrence of LREs (supporting Cognition Hypothesis), this pattern did not hold true for all the tasks and proficiency levels. Moreover, the observed increase was mostly in lexical LREs rather than in grammatical ones, which can indicate more focus on meaning than form (more in line with Skehan's Model). More importantly, neither of the models seemed able to justify why the overall 
occurrence of correctly resolved LREs as well as the perceived learning opportunities by learners did not vary significantly.

The current study had a number of limitations. First of all, this study was based on a small number of EFL learners in only one private language institute. Additionally, the participants only performed four tasks of two types (picture narration and picture difference) only once. Thirdly, only two factors of Cognition Hypothesis (i.e. reasoning demands and number of elements) were manipulated in this study. Therefore, great care should be exercised in generalizing the findings of this study to other contexts.

Future studies may investigate the effects of task complexity on the occurrence of LREs incorporating a greater number of task types and manipulating more dimensions of task complexity as laid down by Robinson. In addition to a greater sample of participants, it may also be helpful to consider the teaching methods and the learning strategies taught to the participants before embarking on such a study for the possible observed differences might be due not only to manipulating task complexity but also to how learners are trained to deal with increased complexity.

In the end, the current study provides insights on task design and implementation in a variety of EFL settings and different proficiency levels indicating the point that increasing task complexity should be done with great care and caution otherwise it may not bear any fruit.

\section{ACKNowledgement}

We thank all the participants, and appreciate the views and comments of the reviewers. All errors are ours.

\section{REFRENCES}

Bygate, M. (2001). «Effects of task repetition on the structure and control of oral language», in M. Bygate et al. (eds.), Researching Pedagogic Tasks: Second Language Learning Teaching and Testing. Harlow: Pearson Education, 23-48.

Bygate, M., Skehan, P., Swain, M. (eds.)(2001). Researching Pedagogic Tasks: Second Language Learning, Teaching and Testing. Harlow: Pearson Education.

Crookes, G., Gass, S.M. (1993a). Tasks and Language Learning: Integrating Theory and Practice. Clevedon: Multilingual Matters.

Crookes, G., Gass, S.M. (1993b). Tasks in a Pedagogical Context: Integrating Theory and Practice. Clevedon: Multilingual Matters.

Ellis, R. (2003). Task-based Language Learning and Teaching. Oxford: Oxford University Press.

Ellis, R. (ed.) (2005). Planning and Task Performance in a Second Language. Amsterdam: John Benjamins.

Foster, P., Skehan, P. (1996). «The influence of planning and task type on second language performance», in Studies in Second Language Acquisition, 18: 299-323.

Gass, S.M. (2003). Input, Interaction, and the Second Language Learner. Mahwah, NJ: Lawrence Erlbaum Associates. 
Gass, S.M., Mackey, A. ( 2007). «Input, interaction and output in SLA», in J. Williams and B. Van Pattern (eds.), Theories in Second Language Acquisition. Mahwah, NJ: Lawrence Erlbaum, 175-199.

Gass, S.M., Mackey, A., Fernandez, M., Alvarez-Torres, M. (1999). «The effects of task repetition on linguistic output», in Language Learning, 49: 549-580.

Gilabert, R. (2005). Task Complexity and L2 Narrative Oral Production. Unpublished Doctoral Dissertation. Barcelona: University of Barcelona.

Iwashita, N. (2001). «The effect of learner proficiency on corrective feedback and modified output in nonnative-nonnative interaction», in System, 29: 267-287.

Iwashita, N., MacNamara, T., Elder, C. (2001). "Can we predict task difficulty in an oral proficiency test: exploring the potential of an information processing approach to task design», in Language Learning, 51: 401-436.

Kim, Y. (2008). «The contribution of collaborative and individual tasks to the acquisition of L2 vocabulary», in Modern Language Journal, 92: 114-130.

Kim, Y., McDonough, K. (2008). «The effect of interlocutor proficiency on the collaborative dialogue between Korean as a second language learners», in Language Teaching Research, 12: 211-234.

Kim, Y. (2009). «The effects of task complexity on learner-learner interaction», in System, 37: 254268.

Kuiken, F., Mos, M., Vedder, I. (2005). «Cognitive task complexity and second language writing performance)», in S. Foster-Cohen (ed.), Eurosla Yearbook, vol. 5. Amsterdam: John Benjamins, 195-222.

Kuiken, F., Vedder, I. (2008). «Cognitive task complexity and written output in Italian and French as a foreign language», in Journal of Second Language Writing, 17: 48-60.

Lee, Y. ( 2002). Effects of Task Complexity on the Complexity and Accuracy of Oral Production in L2 Korean. Unpublished Doctoral Dissertation, Manoa, Hawaii: University of Hawai'i.

Leeser, M.J. (2004). «Learner proficiency and focus on form during collaborative dialogue», in Language Teaching Research, 8: 55-81.

Long, M. (1985) «A role for instruction in second language acquisition: Task-based language teaching)», in K. Hyltenstam and M. Pienemann (eds.), Modeling and Assessing Second Language Acquisition, vol. 18. Clevedon: Multilingual Matters, 77-99.

Long, M. (1996). «The role of the linguistic environment in second language acquisition», in W.C. Ritchie and T.K. Bhatia (eds.), Handbook of Research on Language Acquisition. New York: Academic Press, 413-468.

Mackey, A. (2007a). «Introduction: the role of conversational interaction in second language acquisition», in A. Mackey (ed.), Conversational Interaction in Second Language Acquisition. Oxford: Oxford University Press, 1-26.

Mackey, A. (2007b). «Interaction as practice», in R. DeKeyser (ed.), Practice in Second Language. Cambridge: Cambridge University Press, 85-110.

Mackey, A., Oliver, R., Leeman, J. (2003). «Interactional input and the incorporation of feedback: an exploration of NS-NNS and NNSNNS adult and child dyads», in Language Learning, 53: 35-66.

Mackey, A., Silver, R.E. (2005). «Interactional tasks and English L2 learning by immigrant children in Singapore», in System, 33: 239-260.

McDonough, K. (2004). «Learner-learner interaction during pair and small group activities in a Thai EFL context», in System, 32: 207-224. 
Nuevo, A. (2006). Task Complexity and Interaction: L2 Learning Opportunities and Development. Unpublished Doctoral Dissertation, Washington, DC: Georgetown University.

Ojima, M. (2006). «Concept mapping as pre-task planning: A case study of three Japanese ESL writers», in System, 34: 566-585.

Oliver, R. (1995). «Negative feedback in child NS-NNS conversation. Studies in Second Language», in Acquisition, 17: 459-481.

Ong, J., Zhang, L.J. (2010). «Effects of task complexity on the fluency and lexical complexity in EFL students' argumentative writing», in Journal of Second Language Writing, 19: 218233.

Pica, T., Kanagy, R., Falodun, J. (1993). «Choosing and using communication tasks for second language teaching and research», in G. Crookes and S. Gass (eds.), Tasks in Language Learning: Integrating Theory and Practice. Clevedon: Multilingual Matters, 9-34.

Philp, J., Oliver, R., Mackey, A. (2006). "The impact of planning time on children's task-based interactions», in System, 34: 547-565.

Robinson, P. (1995). «Task complexity and second language narrative discourse», in Language Learning, 45: 99-140.

Robinson, P. (2001a). «Task complexity, task difficulty, and task production: exploring interactions in a componential framework», in Applied Linguistics, 22: 27-57.

Robinson, P. (2001b). «Task complexity, cognitive resources and syllabus design: a triadic framework for examining task influences on SLA)», in P. Robinson (ed.), Cognition and Second Language Instruction. Cambridge: Cambridge University Press, 287-318.

Robinson, P. (2003). «The Cognition Hypothesis: Task design, and adult task-based language learning», in Second Language Studies, 21: 45- 105.

Robinson, P. (2005). «Cognitive complexity and task sequencing: studies in a componential framework for second language task design», in IRAL, 43: 1-32.

Robinson, P. (2007a). "Criteria for classifying and sequencing pedagogic tasks», in M.P. GarciaMayo (ed.), Investigating Tasks in Formal Language Settings. Clevedon: Multilingual Matters, 7-26.

Robinson, P. (2007b). «Task complexity, theory of mind, and intentional reasoning: effects on L2 speech production, interaction, uptake and perceptions of task difficulty», in IRAL, 45: 193-213.

Robinson, P., Gilabert, R. (2007). «Task complexity, the cognition hypothesis and second language learning and performance», in IRAL, 45: 161-176.

Robinson, P., Ting, S., Urwin, J. (1995). «Investigating second language task complexity», in RELC Journal, 25: 62-79.

Ross-Feldman, L. (2007). «Interaction in the L2 classroom: Does gender influence learning opportunities?», in A. Mackey (ed.), Conversational Interaction in Second Language Acquisition. Oxford: Oxford University Press, 53-77.

Samuda, V., Bygate, M. (2008). Tasks in Second Language Learning. New York: Palgrave Macmillan. Skehan, P. (1998). A cognitive approach to language learning. Oxford: Oxford University Press. Skehan, P. (2001). «Tasks and language performance assessment», in M. Bygate, P. Skehan, \& M. Swain (eds.), Researching pedagogic tasks: Second language learning, teaching and testing. Harlow, UK: Pearson Education, 167-185.

Skehan, P. (2003). «Task-based instruction», in Language Teaching, 36: 1-14. 
Skehan, P., Foster, P. (1999). «The influence of task structure and processing conditions on narrative retellings», in Language Learning, 49: 93-100.

Skehan, P., Foster, P. (2001). «Cognition and tasks», in P. Robinson (ed.), Cognition and second language instruction. Cambridge: Cambridge University Press, 183-205.

VanPatten, B. (1990). «Attending to form and content in the input: An experiment in consciousness», in Studies in Second Language Acquisition, 12: 287-301.

Swain, M., Lapkin, S. (1998). «Interaction and second language learning: two adolescent French immersion students working together», in The Modern Language Journal, 82: 320-337. 


\section{Appendix A: Questionnaire (partially based on Kim, 2009)}

Dear Participant: Read the statements below. Then, indicate your extent of agreement or disagreement by circling one of the numbers from one to nine.

Task 1 (Narrating a story based on the ordered pictures)

1. I thought this task was difficult. 1 I thought this task was easy.

2. This task was more difficult than task 2 . This task was less difficult than task 2 .

3. This task did not provide any learning opportunities. 123456789 This task provided a lot of learning opportunities.

Task 2 (Narrating a story based on shuffled pictures)

1. I thought this task was difficult. I thought this task was easy.

2. This task was more difficult than task 1 . This task was less difficult than task 1 .

3. This task did not provide any learning opportunities. 123456789 This task provided a lot of learning opportunities.

Task 3 (Finding differences between pictures: less elements)

1. I thought this task was difficult. I thought this task was easy.

2. This task was more difficult than task 4 . This task was less difficult than task 4 .

3. This task did not provide any learning opportunities. This task provided a lot of learning opportunities.

Task 4 (Finding differences between pictures: more elements)

1. I thought this task was difficult. I thought this task was easy.

2. This task was more difficult than task 3 .

This task was less difficult than task 3 .

3. This task did not provide any learning opportunities.

This task provided a lot of learning opportunities. 